\title{
Information Technology Capabilities, Organizational Agility, and Competitive Advantage: A Study of Micro, Small, and Medium Enterprises in Indonesia
}

\author{
Lovely $^{1}$, Ridhotama Shanti D. Ottemoesoe ${ }^{2 *}$, Devie $^{3}$ \\ 1,2,3 Petra Christian University \\ Jl. Siwalankerto No.121-131, Siwalankerto, Wonocolo, Surabaya, Jawa Timur, Indonesia \\ ${ }^{*}$ Corresponding author; Email: ${ }^{1}$ lovelyzheng98@ gmail.com; ${ }^{2 *}$ shanti@ petra.ac.id; ${ }^{3}$ dave@ petra.ac.id
}

\begin{abstract}
This paper aims to explore the relationship between information technology (IT) capabilities and competitive advantage, with organizational agility as a mediator, in the case of micro, small, and medium enterprises engaged in the fashion industry in Indonesia. Data were collected by distributing questionnaires to 180 small to medium-sized enterprises in Indonesia's fashion industry that have used e-commerce platforms to conduct their business activities. The data were analyzed using partial least squares structural equation modeling (PLS-SEM) in SmartPLS 3.0 software. The study suggests that IT capabilities significantly influence organizational agility and competitive advantage. Therefore, the study can serve as a basis for the Indonesian government to promote digitalization and the use of e-commerce among micro, small, and medium enterprise owners in order to face changes in the market and remain competitive. It can also be beneficial for business owners and managers that aim to increase awareness of the importance of technology in their business operations. The work of this paper deepens the understanding of the relationship between IT capabilities, organizational agility, and competitive advantage, which are becoming increasingly important in the current digitalized and ever-changing business environment. It enriches the literature about micro, small and medium enterprise that is related to their IT capabilities level, how they use it to handle changes and factors that contributes in obtaining competitive advantage.
\end{abstract}

Keywords: Information Technology Capabilities; Competitive Advantage; Organizational Agility; Small-Medium Enterprise.

\section{Introduction}

Micro, Small and Medium Enterprise (MSME) is a crucial part of Indonesian economics. In 2018, there are 64.194.057 MSMEs, much more than the number of Large Enterprises that only counts 5.550 business units(Ministry of Cooperatives and SMEs, 2018) . To further advance the MSMEs, the encouragement for 'go digital go online' is needed to increase their competitiveness (Ministry of National Development Planning, 2019). It is supported by the growth of e-commerce value in Indonesia to $78 \%$, which is the highest in the world and has to be utilized by businesses (Ministry of Communication and Information Technology, 2019a).

MSMEs move in several industries in Indonesia, one of which is the fashion industry. The fashion industry is an industry that covers creative activities related to the creation of clothing design, footwear design, and other fashion accessories design, production of fashion clothes and accessories, product line consulting, and fashion products distribution (Ministry of Communication and Information Technology,
$2019 b)$. The fashion industry is one of the biggest subsectors of the creative economy industry, with a contribution of $18.15 \%$ for that industry in 2018 (Ministry of Industry, 2020). One of the fashion industries that receive special attention from the Indonesian government is Muslim fashion products. The domestic consumption for these products was USD 20 billion, and it had a growth rate of 18.20\% in September 2019 (Ministry of Industry, 2019).

As the world is entering the 4.0 industrial revolution, digital technology is needed by creative industry businesses for development. For example, through the e-commerce platform, many cultural and creative products of local Indonesian people are traded (Ministry of Communication and Information Technology 2019b). Because of that, information technology capabilities have become significant in this industry.

The importance of having information technology becomes vital because of the COVID19 that causes significant losses to business activities. The use of technology has become more crucial than ever to avoid a total closure of economic activities (Akpan, Soopramanien, \& Kwak, 2020). MSME businesses will try to utilize 
e-commerce and social media platforms to reach customers and earn income as COVID-19 forces people to stay at home (Susanty, 2020). In this situation, businesses that can survive and take the chance are those who are connected online (Benyamin, 2020). Aside from that, information technology is important because it is the main source of organizational agility to face suppliers and consumers in an uncertain and unstable condition (Qosasi, Maulina, et al., 2019).

Organizational agility is essential to the fashion industry because change is inevitable in this industry. There will always be a new design, style, and trends that will change supplies and demands. Thus, success or failure in this industry is highly determined on the organizations' flexibility and responsiveness, which depends on the organizational agility (Čiarnienè \& Vienažindienè, 2014). Previous studies propose that technology is an antecedent of organizational agility, especially when a company can embrace and develop technological capabilities (Chakravarty, Grewal, \& Sambamurthy, 2013; Chen et al., 2014; Ngai, Chau, \& Chan, 2011). Organizational agility influences company performance and the amounts and variations of competitive actions taken by the companies in response to the changing environment (Tallon, Queiroz, Coltman, \& Sharma, 2019).

On the other hand, process integration and automation by information technology can make it hard for companies to enact changes. The stiff process and the possibility of unexpected challenges can cause organizations to lose their agility (Mao, Liu, \& Zhang, 2015). Aside from that, even though the technology used may be the latest one, the users may not have the ability to operate it, and consequently, it will not give any competitive advantage (Qosasi, Maulina, et al., 2019). There were studies that research information technology, agility, and competitive advantage but they only used two of these variables and analyzed them with other variables. There have not been many previous studies that combine all three variables used, thus there is a need to understand how the IT capabilities may be a source of organizational agility and competitive advantage.

\section{Literature review}

\subsection{IT Capabilities}

Information Technology (IT) Capability is the ability to obtain, fuse, and apply information technology resources to fulfill business needs and take advantage of business opportunities (Bi, Davison, \& Smyrnios, 2019: Santoso and Siagian, 2019). It enables MSMEs to gather customer information at a low cost, which will increase marketing effectiveness and the ability to perform market segmentation and product differentiation. It allows MSMEs to quickly, and with competitive cost, provide suitable products based on information gathered (Neirotti, Raguseo, \& Paolucci, 2017).

IT Capability is also valuable for MSMEs to build a relationship with business partners (Jiputra et al., 2020). They need to cooperate with their business partners to renew themselves by exploiting business competitions and exploring new competencies for innovations (Bi et al., 2019). Developing and managing the relationship between companies count as strategic assets that can influence business performances (Carlo, Lyytinen, \& Rose, 2012; Du, Lai, Cheung, \& Cui, 2012).

\subsection{Organizational Agility}

Organizational agility is the ability to handle changes that often happen unexpectedly in the business environment through quick and innovative responses by taking advantage of the changes as an opportunity to grow and thrive ( $\mathrm{Lu}$ \& Ramamurthy, 2011). Organizational agility counts as a main competency for organizations that experience persistent changes in the business environment and high competitive pressure (Panda \& Rath, 2016). The importance of organizational agility also applies to MSMEs because they operate in a turbulent and dynamic business environment, signified with the changes in customer's needs, increased competition, greater flexibility, and the rapid development of innovative products/services (Parida, Oghazi, \& Cedergren, 2016).

\subsection{Competitive Advantage}

Competitive advantage is how far an organization can create a position that can be maintained over its competitors (Bratić, 2011). It can be seen from the implementation of a company's strategy to achieve the goal of cost reduction, to exploit market opportunities, and neutralize competitive threats (Qosasi, Permana, Muftiadi, Purnomo, \& Maulina, 2019). In today's ever-changing business environment, competitive advantage is crucial for any business continuity. A business must measure its competitive advantage as a way to evaluate and highlight how it competes (Yaghoobi, Bakhshimazdeh, \& 
Alikhasi, 2014). To have a competitive advantage, an organization has to have an innovation or differentiation over their competitors, and in the eyes of the customers, it has to have a high value, of which the value, benefit, and sentimental effect cannot be fulfilled by other products or services (Wingwon, 2012).

\subsection{IT Capabilities and Organizational Agility}

The presence of information technology allow businesses to collect relevant data for decision making. IT capabilities help them exchange information and communicate with external partners promptly. Therefore, IT capabilities applied within business activities and processes will help shorten the time to respond to changes, process information, and implement strategies to increase agility (Chen et al., 2014).

Qosasi et al. (2019) found that IT capabilities affect MSME agility because adequate capabilities enable organizations to identify and handle more business opportunities, customer relationships, and resources more effectively (Qosasi, Maulina, et al., 2019; Jiputra et al., 2020). Meanwhile, Ravichandran (2018) found that digital platforms characterized by flexible infrastructure, combined with the deployment of enterprise software across multiple platforms, have a positive impact on organizational agility (Ravichandran, 2018).

H1 : IT capabilities influence organizational agility.

\subsection{Organizational Agility and Competitive Advantage}

MSMEs are facing changes in the environment and organizational agility is the key to deal with these changes. Agility has become a crucial competency since it can have a profound impact on performance (Ravichandran, 2018). MSMEs must have flexibility and adaptability to gain a competitive advantage, because, through both, they can respond proactively to change, especially unexpected changes that can have a significant impact (Ong, Ismail, \& Goh, 2010). MSMEs must develop agility to continuously collect, monitor, and process changing environmental signals, make innovative decisions, and rapidly adjust processes to take advantage of market opportunities, and thereby facilitating the achievement of a sustainable competitive advantage (Bi, Davison, Kam, \& Smyrnios, 2013).
Qosasi et al. (2019) found that organizational agility affects the competitive advantage of MSMEs selling clothing in traditional markets in Jakarta, Indonesia. Today's MSMEs must be able to respond quickly, have short product cycles, and adapt to changes in consumer demand (Qosasi, Maulina, et al., 2019). Wu et al. (2017) stated that organizational agility in the supply chain is a required component in achieving firm performance (Setiabudi et al., 2021). and competitive advantage (Wu et al., 2017). Such agility is considered as the ability to explore unexpected environmental changes and exploit these changes to increase competitive advantage (Wu, Tseng, Chiu, \& Lim, 2017).

$\mathrm{H} 2$ : Organizational agility influences competitive advantage.

\subsection{IT Capabilities and Competitive Advantage}

According to the Resource-Based View theory, organizations are successful and achieves a sustainable competitive advantage by taking into account the resources/capabilities that they have in strategy formulation. Although information technology resources such as hardware or software are rarely used for the goal of creating and maintaining competitive advantage, the ability to utilize information technology resources helps the organizations to not only creating value but also achieving sustainable competitive advantage (Bi et al., 2013).

For MSMEs, using and utilizing information technology is a way to upgrade products and business processes to confront the pressures from competitors (Adeniran \& Johnston, 2016). Competitors can easily imitate information technology resources, but the way to incorporate those resources into the organizations' goals so that IT capabilities as a whole is hard to obtain and hard to imitate, and so it gives competitive advantage (Bi et al., 2013).

Neirotti and Raguseo (2017) find that capabilities on information technology will grow a bigger economic value for MSMEs than its competitors in terms of growth, income, and profitability (Neirotti \& Raguseo, 2017) Aside from that, the research of Mithas et al. (2011) highlights the roles and importance of information management capabilities to enable business advantage and to create and maintain competitive advantage (Mithas, Ramasubbu, \& Sambamurthy, 2011). 
H3 : IT capabilities influence competitive advantage.

\subsection{IT Capabilities, Organizational Agility, and Competitive Advantage}

IT capabilities can influence companies' performance through the role of resource mediation or other abilities, one of which is organizational agility. An organization's agility depends on the organization's capability in implementing and utilizing information technology resources. IT capabilities enable companies to strengthen the business process by imparting speed, solidity, and flexibility. Meanwhile, organizational agility gives opportunities to the companies to achieve high profitability, profit from investments, sales growth, and market share growth. On the contrary, without agility, companies only have a small chance to achieve superior performance (Chen et al., 2014). Information technology gives influence to the companies through a complementary relationship with assets and other companies' capabilities, and agility is an important mediator to see the influence of IT capabilities on a company's performance (Liu, Ke, Wei, \& Hua, 2013; Santoso and Siagian, 2019; Jiputra et al., 2020).

$\mathrm{H} 4$ : Organizational agility mediates the influence of IT capabilities on competitive advantage.

\section{Methods}

\subsection{Sampling}

Given the objective of this research, the target population consists of micro, small, and medium enterprises that are involved in Indonesia's fashion industry and use both ecommerce and social media platforms to market their product and build relationships with customers or suppliers. The unit of analysis is the owner or manager of the enterprise as this person usually has optimal understanding of their own business, including the importance of information technology in the business, how the business deals with changes, and how they view their business compared to other competitors in the market; and is, therefore, in the best position to answer the questionnaire. The sampling technique used in this research is convenience sampling. Each person who received the questionnaire and agreed to give the required information to the researcher is included as a sample in this research as long as they met the respondent criteria (Sekaran \& Bougie, 2016).

\subsection{Data Collection Methods and Processes}

The questionnaire in this research is administered through Google Forms and mobilebased survey service. It includes a cover letter stating the objective of the study as well as the instructions for the survey. A total number of 500 questionnaires were distributed, and 215 were returned, from which 35 questionnaires were answered with the same numbers from start to finish and so cannot be used. A total of 180 questionnaires can be processed for further analysis, yielding an effective response rate of 36 percent.

This research uses the partial least squares (PLS) data analysis technique, part of the structural equation model (SEM). Validity and reliability were checked to evaluate the measurement model. Convergent validity assesses whether outer loadings are above 0.70 and the average variance extracted (AVE) is above 0.50 . For social science research, especially on newly developed measurement scales, it is often found that outer loading values are below 0.70 . Therefore, indicators that have an outer loading value between $0.40-0.70$ can be considered for deletion only when removal of the indicator is required and can increase the AVE value (Hair, Hult, Ringle, \& Sarstedt, 2017).

Discriminant validity is assessed through the Fornell Larcker criterion. It compares the square root value of the AVE: the value must be greater than the highest correlation value for other variables. Additionally, an examination of the cross-loadings of each indicator is performed. This method requires the value of the outer loading of each indicator to be higher than the value of the loading of the other variables. The reliability checks performed are Cronbach's alpha value and composite reliability. These are used to measure the internal consistency of the indicators that constitute a variable. The minimum value for Cronbach's alpha is 0.60 , and the expected composite reliability value is $0.70-0.90$ (Hair et al., 2017).

The structural model considers the $\mathrm{R}^{2}$ value. This represents the variance of the dependent variable which can be explained by the independent variable (Hair et al., 2017). Meanwhile, the $\mathrm{Q}^{2}$ value measures predictive relevance. When the value is greater than 0 , the 
independent variable can predict the dependent variable with relevance. $\mathrm{Q}^{2}$ values are obtained using a blindfolding procedure for a certain omission distance (Hair et al., 2017). Hypothesis testing is performed using a bootstrapping procedure using a significance level of 5\%, which implies that the $\mathrm{p}$ values must be less than 0.05 for the relationship to be significant. Hypothesis testing generates the $\mathrm{t}$-statistics value. This must be above 1.96 , and the p-value below 0.05 , for two-tailed testing if the hypothesis is to be accepted (Hair et al., 2017).

\subsection{Measures}

The questionnaire consists of 3 parts. The first part contains screening questions to ensure that the respondent is a part of the target population. The second part contains questions of demographics and current business conditions. The third part contains questions of IT capabilities (Bi et al., 2019), Organizational agility (Lu \& Ramamurthy, 2011), and Competitive advantage (Bratić, 2011) that is measured with the 5 Likert scales starting from strongly disagree to strongly agree.

\section{Results}

Table 1 represents the respondents' demographic profile. As described above, only businesses engaged in the fashion industry and use e-commerce platforms are considered as samples. The sample is dominated by micro and small businesses with less than 25 employees, which is $98.88 \%$. The rests are medium companies (1.12\%; 50-75 employees). Each respondent can answer more than one ecommerce platform that they use for business, where most answer Shopee, used by 155 out of 180 respondents. About the owners or business managers' characteristics, $4.11 \%$ are between 26 to 40 years old. They can be classified as educated people; as $53.33 \%$ of the samples have completed a bachelor/equivalent or graduate/postgraduate degree.

Table 2 shows the indicators of the reliability and validity of constructs, then Table 3 shows the correlation matrix and the square root of AVE. Table 4 shows the hypothesis test results. The test result shows that IT capabilities positively and significantly influence organizational agility and competitive advantage, thus $\mathrm{H} 1$ an $\mathrm{H} 2$ are accepted. Organizational agility positively and significantly influence competitive advantage, thus $\mathrm{H} 3$ is accepted. Organizational agility is a variable that significantly mediates the influence of IT capabilities on competitive advantage, thus H4 is accepted.

Table 1. Demographic Profile

\begin{tabular}{|c|c|c|}
\hline & Freq. & Percentage \\
\hline \multicolumn{3}{|l|}{ 1. Gender } \\
\hline Male & 65 & $36.11 \%$ \\
\hline Female & 115 & $63.89 \%$ \\
\hline \multicolumn{3}{|l|}{ 2. Age } \\
\hline$<17$ years old & 2 & $1.11 \%$ \\
\hline 17 years old -25 years old & 72 & $40.00 \%$ \\
\hline 26 years old -40 years old & 83 & $46.11 \%$ \\
\hline 41 years old -55 years old & 15 & $8.33 \%$ \\
\hline$>55$ years old & 8 & $4.44 \%$ \\
\hline \multicolumn{3}{|l|}{ 3. Last Education } \\
\hline Junior High School & 7 & $3.89 \%$ \\
\hline Senior High School & 63 & $35.00 \%$ \\
\hline Diploma/Associate & 14 & $7.78 \%$ \\
\hline Bachelor & 90 & $50.00 \%$ \\
\hline Undergraduate/Graduate & 6 & $3.33 \%$ \\
\hline \multicolumn{3}{|l|}{ 4. E-commerce platform used } \\
\hline Shopee & 155 & $47.99 \%$ \\
\hline Tokopedia & 93 & $28.79 \%$ \\
\hline Lazada & 25 & $7.74 \%$ \\
\hline Bukalapak & 25 & $7.74 \%$ \\
\hline OLX & 14 & $4.33 \%$ \\
\hline Blibli & 11 & $3.41 \%$ \\
\hline \multicolumn{3}{|l|}{$\begin{array}{l}\text { 7. Length of time using e- } \\
\text { commerce platform(s) for }\end{array}$} \\
\hline business & 94 & $52.22 \%$ \\
\hline$<1$ years & 79 & $43.89 \%$ \\
\hline $1-5$ years & 7 & $3.89 \%$ \\
\hline$>5$ years & & \\
\hline \multicolumn{3}{|l|}{ 8. Number of employees } \\
\hline$<25$ people & 178 & $98.88 \%$ \\
\hline $26-50$ people & 1 & $0.56 \%$ \\
\hline $51-75$ people & 1 & $0.56 \%$ \\
\hline
\end{tabular}

IT capabilities affect organizational agility in MSMEs positively and significantly because with adequate capabilities, MSMEs can improve their relationships with customers, suppliers, and business partners, which allow them to become agile in making decisions, especially when facing changes in the market (Qosasi, et al., 2019). 
Table 2. Indicators of the Reliability and Validity of Constructs

\begin{tabular}{|c|c|c|c|c|}
\hline Variable and Empirical Indicator & $\begin{array}{l}\text { Outer } \\
\text { Loading }\end{array}$ & $\begin{array}{l}\text { Cronbach's } \\
\text { Alpha }\end{array}$ & $\begin{array}{l}\text { Composite } \\
\text { Reliability }\end{array}$ & AVE \\
\hline IT Capabilities (Bi et al., 2019) & & 0.873 & 0.902 & 0.568 \\
\hline $\begin{array}{l}\text { 1. We have the information and communication technology } \\
\text { infrastructure that can support the use of e-commerce } \\
\text { platforms }\end{array}$ & $\begin{array}{l}0.732 \\
0.757\end{array}$ & & & \\
\hline $\begin{array}{l}\text { 2. We can flexibly develop our existing information and } \\
\text { communication technology infrastructure to keep up with the } \\
\text { e-commerce platform development }\end{array}$ & 0.755 & & & \\
\hline $\begin{array}{l}\text { 3. We understand how our business' vision and mission can be } \\
\text { achieved the use of e-commerce platforms }\end{array}$ & 0.793 & & & \\
\hline $\begin{array}{l}\text { 4. We understand that investment in information and } \\
\text { communication technology is very important to support our } \\
\text { use of e-commerce platform }\end{array}$ & 0.737 & & & \\
\hline $\begin{array}{l}\text { 5. We communicate with our customers through information and } \\
\text { communication technology such as e-commerce and social } \\
\text { media platform }\end{array}$ & 0.729 & & & \\
\hline $\begin{array}{l}\text { 6. We communicate with our suppliers through information and } \\
\text { communication technology such as e-commerce and social } \\
\text { media platform }\end{array}$ & 0.770 & & & \\
\hline $\begin{array}{l}\text { 7. We communicate with our business partners through } \\
\text { information and communication technology such as e- } \\
\text { commerce and social media platform }\end{array}$ & & & & \\
\hline Organizational Agility (Lu and Ramamurthy, 2011) & & 0.785 & 0.854 & 0.522 \\
\hline 1. $* *$ We can fulfill the demands that require fast responses & - & & & \\
\hline $\begin{array}{l}\text { 2. We can quickly increase or decrease our production level to } \\
\text { adjust to the market's demands }\end{array}$ & 0.798 & & & \\
\hline $\begin{array}{l}\text { 3. We can quickly do adjustment if there is any supply disruption } \\
\text { from our suppliers }\end{array}$ & 0.665 & & & \\
\hline 4. We can quickly and properly make decisions to face market & 0.803 & & & \\
\hline 5. We keep on looking for ways to serve our market better & 0.675 & & & \\
\hline $\begin{array}{l}\text { 6. We consider market changes as opportunities that have to be } \\
\text { utilized quickly }\end{array}$ & 0.724 & & & \\
\hline Competitive Advantage (Bratić, 2011) & & 0.870 & 0.898 & 0.508 \\
\hline 1. We offer competitive prices compared to our competitors & 0.738 & & & \\
\hline 2. We can offer similar/lower prices than our customers & 0.702 & & & \\
\hline 3. We can compete in product/service quality & & & & \\
\hline 4. ** We offer reliable products/services & 0.749 & & & \\
\hline 5. We deliver customers' orders on time & - & & & \\
\hline 6. We have a reliable delivery service & 0.709 & & & \\
\hline 7. We offer products that can be adjusted to our customer's & 0.708 & & & \\
\hline $\begin{array}{ll}\text { needs } \\
\text { 8. We respond to our customer's requests on new features }\end{array}$ & 0.749 & & & \\
\hline 9. * We are a pioneer in launching new products to the market & 0.760 & & & \\
\hline 10. We launch our products faster than our competitors & - & & & \\
\hline & 0.665 & & & \\
\hline
\end{tabular}

Notes

* = indicator reduced because does not fulfill the AVE requirement(s)

** = indicator reduced because does not fulfill the Fornell-Larcker

Criterion requirement(s)

Table 3. Correlation Matrix and the Square Root of AVE: Fornell-Larcker criteria

\begin{tabular}{lccc}
\hline & $\begin{array}{c}\text { IT } \\
\text { Capabilities }\end{array}$ & $\begin{array}{c}\text { Organi- } \\
\text { zational } \\
\text { Agility }\end{array}$ & $\begin{array}{c}\text { Competitive } \\
\text { Advantage }\end{array}$ \\
\hline Fornell Larcker Criterion & & \\
\hline $\begin{array}{l}\text { IT } \\
\text { Capabilities }\end{array}$ & 0.723 & & \\
\hline $\begin{array}{l}\text { Organizational } \\
\text { Agility }\end{array}$ & 0.592 & 0.754 & \\
\hline $\begin{array}{l}\text { Competitive } \\
\text { Advantage }\end{array}$ & 0.693 & 0.600 & 0.735 \\
\hline
\end{tabular}

Table 4. Results of the Structural Model

\begin{tabular}{lcccc}
\hline \multicolumn{1}{c}{ Hypothesis } & $\begin{array}{c}\text { Path } \\
\text { Coeff. }\end{array}$ & $\begin{array}{c}\text { T- } \\
\text { Statistics }\end{array}$ & $\begin{array}{c}\text { p } \\
\text { values }\end{array}$ & Result \\
\hline $\begin{array}{l}\text { IT Capabilities } \rightarrow \\
\text { Competitive } \\
\text { Advantage }\end{array}$ & 0.275 & 2,986 & 0.003 & \\
\hline $\begin{array}{l}\text { IT Capabilities } \rightarrow \\
\text { Organizational } \\
\text { Agility } \rightarrow \\
\text { Competitive } \\
\text { Advantage }\end{array}$ & 0.317 & 5,454 & 0.000 & Accepted \\
\hline
\end{tabular}


The agility of MSMEs increases when they can change their business tactics or direction quickly, and this is influenced by their IT capabilities because they can use IT to anticipate, adapt, and react to environmental uncertainties that occur in their business activities (Qosasi, Permana, et al., 2019). Other studies also show that IT capabilities can improve organizational agility (Chen et al., 2014; Degroote \& Marx, 2013; Mao et al., 2015; Ravichandran, 2018).

Organizational agility affects competitive advantage in MSMEs positively and significantly. Organizational agility is considered as the ability to explore unexpected environmental changes and exploit these changes to increase competitive advantage (Wu et al., 2017). If businesses perceive changes in the market as opportunities that must be exploited quickly and can accurately make decisions to deal with market changes, then they will be able to respond to customer demands and be able to launch products faster into the market, thus having a competitive advantage.

Businesses with strong organizational agility can be responsive to customer needs, increase operational flexibility and customer retention, and generally increase revenue while reducing costs (Chen et al., 2014). If businesses continue to look for ways to better serve their market, they will be able to compete in terms of product/service quality that can increase revenue, but at the same time reduce costs so that they can offer competitive prices compared to competitors. Therefore, organizational agility can be a source of competitive advantage if it makes it difficult for competitors to compete and imitate (Qosasi, Maulina, et al., 2019).

IT capabilities significantly and positively influence competitive advantage in MSMEs. It can utilize information technology to build a relationship with customers, suppliers, and business partners to obtain sensitive information or useful information that is used to improve business responsiveness (Cai, Huang, \& Liang, 2014). This is useful for MSME actors in the fashion industry because it can obtain information from suppliers and business partners about what trend is currently popular and in understanding the desires of customers so that they can offer appropriate products.

Businesses can obtain information from customers about the kinds of product models that they want, for example, customers may prefer a fashion trend from certain countries. From the obtained information, MSME can understand the desires of the customers so they can offer products that can be adjusted with the customers' desires, have information from suppliers so they can launch a product faster than their competitors, and obtain information from business partners so they can have a reliable delivery service.

This research result is supported by Neirotti \& Raguseo (2017) who find that IT capabilities significantly influence competitive advantage in terms of profitability and revenue growth (Neirotti \& Raguseo, 2017). Marinagi et al. (2014) also find similar results where information technology influences competitive advantage significantly because it has an important role for supply chain management in that industry (Marinagi, Trivellas, \& Sakas, 2014; Setiabudi et al., 2021).

Organizational agility is a variable that significantly mediates the influence of IT capabilities on competitive advantage. It can be said that the more agile an MSME, the stronger the influence of IT capabilities that it has to obtain a competitive advantage. Thus, it is a good thing for MSMEs to utilize their IT capabilities to achieve agility and utilize that ability to respond to changes quickly. The more agile an SME, the better their ability to serve the market so that it affects competitive advantage.

An organization's agility depends on the company's ability to implement and utilize information technology resources. On the contrary, without agility companies have a small chance to achieve superior performance (Chen et al., 2014). Meanwhile, information technology influences companies through its complementary relationship with assets and other companies' capabilities, and agility is an important mediator to see the impacts of IT capabilities on companies' performance (Liu et al., 2013).

Table 5. $\mathrm{R}^{2}$ Values

\begin{tabular}{lcc}
\hline Dependent variables & $\mathbf{R}^{\mathbf{2}}$ & Adjusted $\mathbf{R}^{\mathbf{2}}$ \\
\hline Organizational Agility & 0.360 & 0.356 \\
Competitive Advantage & 0.528 & 0.523 \\
\hline
\end{tabular}

Table 5 shows the $\mathrm{R}^{2}$ value of each dependent variable. The organizational agility variable shows a value of 0.360 . This means $36 \%$ of that variable can be described by the IT capabilities variable. On the other hand, this shows that $64 \%$ of the organizational agility variable can be described by other variables outside of this research's model. Meanwhile, the competitive advantage variable shows a value of 0.528 . This means that $52.8 \%$ of that variable can be described by the IT capabilities and 
Organizational Agility variable. On the other hand, this shows that $47.2 \%$ of the competitive advantage variable can be described by other variables outside of this research's model. Overall, each variable has a value above zero, which means the model can be considered to be accurate enough to be analyzed based on the existing data.

\section{Discussion}

\subsection{Practical Implications}

This study emphasizes how MSMEs can obtain and maintain a competitive advantage through IT capabilities and organizational agility. Technology plays a significant role in MSMEs in today's society, especially IT that can support business operations. This study focuses on ecommerce platforms as one of the technologies crucial for businesses in this all-digital era.

The owners or managers of MSMEs must develop IT capabilities within their organization, particularly the ability to use e-commerce platforms to achieve their business objectives. Essentially, the organization should use this technology to sell products or services. However, in today's ever-changing business environment, businesses must be familiar with and able to use the features and tools provided by e-commerce platforms. They need to understand how to promote or advertise effectively using these platforms, in order to boost sales, increase engagement, and build customer loyalty.

The owners or managers of MSMEs must pay attention to IT capabilities since they influence how well a business responds to changes. With the proper skills, they can build relationships with customers, suppliers, and business partners. And maintaining good relationships with these parties allows owners and managers to gain insights into the market, which can help the business to give a quick and correct response to changes in the market and remain agile.

The results of this study suggest that the IT capabilities and the agility of an organization influence its competitive advantage. It shows that MSMEs must have or develop these two factors to win over their competitors. These factors are necessary for businesses in the fashion industry because fashion trends and styles are always changing. Furthermore, there are many competitors in the fashion market, and therefore remaining competitive is vital.

\subsection{Limitations and Future Research}

This research has limitations because it only used MSMEs in the fashion industry. Also, only 2 out of 180 respondents were medium-sized enterprises, while the others were classified as micro or small. Future studies can use MSMEs from other industries with more evenly distributed respondents from each category. This research only analyzed IT capabilities and organizational agility as the variables that influenced competitive advantage. Future studies can incorporate other variables, such as innovation, entrepreneurship, and organizational learning that can influence the competitive advantage of an MSME. With the addition of new variables in future research models, the researcher hopes that the things that influence the performance and competitive advantage of a business can be understood more comprehensively.

\section{Conclusions}

IT capabilities in MSMEs are useful for sharing information, taking advantage of business opportunities, and achieving agility. In order to respond to market changes quickly and correctly, without being left behind by competitors, IT capabilities are required. When a business has organizational agility, which is supported by IT capabilities, this will affect its competitiveness in the market. As a result, the business can compete based on price, quality, reliability of delivery, product innovation, and time-to-market. This research attempts to make competitive advantage a primary objective that every business must obtain and maintain. This is achievable by adopting IT in business activities and developing the capability to use it.

\section{References}

Adeniran, T. V., \& Johnston, K. A. (2016). The Impacts of ICT Utilisation and Dynamic Capabilities On The Competitive Advantage of South African SMEs. International Journal of Information Technology and Management, 15(1), 59-89. doi.org/10.1504/IJITM.2016. 073915

Akpan, I. J., Soopramanien, D., \& Kwak, D. H. (2020). Cutting-Edge Technologies For Small Business And Innovation In The Era Of COVID-19 Global Health Pandemic. Journal of Small Business and Entrepreneurship, O(0), 1-11. doi.org/10.1080/08276331.2020. 1799294 
Benyamin, M. Y. (2020, April 22). Belajar dari Corona, Digitalisasi UMKM Kian Mendesak . Retrieved July 3, 2020, from Bisnis.com website: ekonomi.bisnis.com/read/20200422/ 9/1230759/belajar-dari-corona-digitalisasiumkm-kian-mendesak

Bi, R., Davison, R. M., Kam, B., \& Smyrnios, K. X. (2013). Developing Organizational Agility Through IT and Supply Chain Capability. Journal of Global Information Management, 21(4), 38-55. doi.org/10.4018/jgim. 2013100103

Bi, R., Davison, R., \& Smyrnios, K. (2019). The Role of Top Management Participation and IT Capability in Developing SMEs' Competitive Process Capabilities. Journal of Small Business Management, 57(3), 1008-1026. doi.org/10.1111/jsbm.12380

Bratić, D. (2011). Achieving a Competitive Advantage by SCM. IBIMA Business Review Journal, 2011, 1-13. doi.org/10.5171/2011. 957583

Cai, Z., Huang, Q., \& Liang, L. (2014). Effects of It Capability and External Integration on Organizational Responsiveness: An Organizational Learning Perspective. Proceedings Pacific Asia Conference on Information Systems, PACIS 2014.

Carlo, J. L., Lyytinen, K., \& Rose, G. M. (2012). A Knowledge-Based Model of Radical Innovation in Small Software Firms. MIS Quarterly, 36(3), 865-895.

Chakravarty, A., Grewal, R., \& Sambamurthy, V. (2013). Information Technology Competencies, Organizational Agility, and Firm Performance: Enabling and Facilitating Roles. Information Systems Research, 24(4), 976997. doi.org/10.1287/isre.2013.0500

Chen, Y., Wang, Y., Nevo, S., Jin, J., Wang, L., \& Chow, W. S. (2014). IT Capability and Organizational Performance: The Roles of Business Process Agility and Environmental Factors. European Journal of Information Systems, 23(3), 326-342. doi.org/10.1057/ejis. 2013.4

Čiarnienè, R., \& Vienažindienè, M. (2014). Agility and Responsiveness Managing Fashion Supply Chain. Procedia - Social and Behavioral Sciences, 150, 1012-1019. doi.org/10.1016/j.sbspro.2014.09.113

Degroote, S. E., \& Marx, T. G. (2013). The Impact of IT on Supply Chain Agility and Firm Performance: An Empirical Investigation. International Journal of Information Management, 33(6), 909-916. doi.org/10.1016/ j.ijinfomgt.2013.09.001

Du, T. C., Lai, V. S., Cheung, W., \& Cui, X. (2012). Willingness to Share Information in A Supply Chain: A Partnership-Data-Process Perspective. Information and Management, 49 (2), 89-98. doi.org/10.1016/j.im.2011.10. 003

Hair, J. F., Hult, G. T. M., Ringle, C., \& Sarstedt, M. (2017). A Primer on Partial Least Squares Structural Equation Modeling (PLS-SEM). Retrieved from books.google.co.id/books? id=JDWmCWAAQBAJ

Jiputra, J.A., Tarigan, Z.J.H., and Siagian, H. (2020). The Effect of Information Technology on Retailer Satisfaction Through Supply Chain Management Practices and RetailerDistributor Relationship in Modern Retailer Surabaya. International Journal of Business Studies, 3(2), 126-134, doi: doi.org/10.9744/ ijbs. 3.2.126-134

Liu, H., Ke, W., Wei, K. K., \& Hua, Z. (2013). The Impact of IT Capabilities on Firm Performance: The Mediating Roles of Absorptive Capacity and Supply Chain Agility. Decision Support Systems, 54(3), 1452-1462. doi.org/10.1016/j.dss.2012.12.016

Lu, Y., \& Ramamurthy, K. (2011). Understanding The Link Between Information Technology Capability and Organizational Agility: An Empirical Examination. MIS Quarterly: Management Information Systems, 35(4), 931-954. doi.org/10.2307/41409967

Mao, H., Liu, S., \& Zhang, J. (2015). How The Effects of IT and Knowledge Capability on Organizational Agility are Contingent on Environmental Uncertainty and Information Intensity. Information Development, 31(4), 358-382. doi.org/10.1177/0266666913518059

Marinagi, C., Trivellas, P., \& Sakas, D. P. (2014). The Impact of Information Technology on the Development of Supply Chain Competitive Advantage. Procedia - Social and Behavioral Sciences, 147, 586-591. doi.org/10.1016/ j.sbspro.2014.07.161

Ministry of Communication and Information Technology. (2019a). Kemkominfo: Pertumbuhan e-Commerce Indonesia Capai 78 Persen. Retrieved May 30, 2020, from kominfo.go.id/ content/detail/16770/kemkominfopertumbuhan-e-commerce-indonesia-capai78-persen/0/sorotan_media

Ministry of Communication and Information Technology. (2019b). Perkembangan Ekonomi Digital di Indonesia: Strategi dan Sektor Potensial. doi.org/10.31227/osf.io/ d89jm 
Ministry of Cooperatives and SMEs. (2018). Perkembangan Data Usaha Mikro, Kecil, Menengah dan Usaha Besar. Retrieved from www.depkop.go.id/uploads/laporan/1580223 129_PERKEMBANGAN DATA USAHA MIKRO, KECIL, MENENGAH (UMKM) DAN USAHA BESAR (UB) TAHUN 2017 2018.pdf

Ministry of Industry. (2019). Kemenperin Dorong Industri Tangkap Peluang Pasar Fesyen Muslim Dunia. Retrieved January 13, 2021, from kemenperin.go.id/artikel/21252/ Kemenperin-Dorong-Industri-TangkapPeluang-Pasar-Fesyen-Muslim-Dunia

Ministry of Industry. (2020, March 9). Sumbang Lebih Rp 1.100 Triliun, Kemenperin Gencar Telurkan Industri Kreatif. Retrieved October 24, 2020, from kemenperin.go.id/artikel/ 21598/Sumbang-Lebih-Rp-1.100-Triliun,Kemenperin-Gencar-Telurkan-IndustriKreatif

Ministry of National Development Planning. (2019). IDF 2019: Modernisasi Umkm Atasi Permasalahan Masyarakat, Bantu Perekonomian Nasional. Retrieved July 3, 2020, from www.bappenas.go.id/id/berita-dan-siaranpers/idf-2019-modernisasi-umkm-atasipermasalahan-masyarakat-bantuperekonomian-nasional/

Mithas, S., Ramasubbu, N., \& Sambamurthy, V. (2011). How Information Management Capability Influences Firm Performance. MIS Quarterly: Management Information Systems, 35(1), 237-256. doi.org/10.2307/23043496

Neirotti, P., \& Raguseo, E. (2017). On The Contingent Value of IT-Based Capabilities for The Competitive Advantage of Smes: Mechanisms and Empirical Evidence. Information and Management, 54(2), 139-153. doi.org/10.1016/j.im.2016.05.004

Neirotti, P., Raguseo, E., \& Paolucci, E. (2017). Flexible Work Practices and The Firm's Need for External Orientation: An Empirical Study of SMEs. Journal of Enterprise Information Management, 30(6), 922-943. doi.org/ 10.1108/JEIM-04-2016-0090

Ngai, E. W. T., Chau, D. C. K., \& Chan, T. L. A. (2011). Information Technology, Operational, and Management Competencies for Supply Chain Agility: Findings from Case Studies. Journal of Strategic Information Systems, 20(3), 232-249. doi.org/10.1016/j.jsis.2010. 11.002

Ong, J. W., Ismail, H. Bin, \& Goh, G. G. G. (2010). The Competitive Advantage of Small and Medium Enterprises (SMEs): The Role of Entrepreneurship and Luck. Journal of Small Business and Entrepreneurship, 23(3), 373391.doi.org/10.1080/08276331.2010.105934 91

Panda, S., \& Rath, S. K. (2016). Investigating the Structural linkage between IT capability and Organizational agility: A Study on Indian Financial Enterprises. Journal of Enterprise Information Management, 29(5).

Parida, V., Oghazi, P., \& Cedergren, S. (2016). A Study of How ICT Capabilities Can Influence Dynamic Capabilities. Journal of Enterprise Information Management, 29(2), 179-201. doi.org/10.1108/JEIM-07-2012-0039

Qosasi, A., Maulina, E., Purnomo, M., Muftiadi, A., Permana, E., \& Febrian, F. (2019). The impact of Information and Communication Technology capability on the competitive advantage of small businesses. International Journal of Technology, 10(1), 167-177. doi.org/10.14716/ijtech.v10i1.2332

Qosasi, A., Permana, E., Muftiadi, A., Purnomo, M., \& Maulina, E. (2019). Building SMEs' Competitive Advantage and The Organizational Agility of Apparel Retailers in Indonesia: The Role of ICT As An Initial Trigger. Gadjah Mada International Journal of Business, 21(1), 69-90. doi.org/10.22146/ gamaijb.39001

Ravichandran, T. (2018). Exploring The Relationships Between IT Competence, Innovation Capacity and Organizational Agility. Journal of Strategic Information Systems, 27(1), 22-42. doi.org/10.1016/j.jsis.2017.07. 002

Santoso, O.G. and Siagian, H. (2019). Influence of IT Application to Organizational Performance mediated by warehouse management and customer relationship management. International Journal of Business Studies, 2(1), 44-52, doi: doi.org/10.9744/ijbs.2.1.44-52

Sekaran, U., \& Bougie, R. (2016). Research Methods for Business: A Skill-Building Approach (Seventh ed). Chichester, West Sussex: John Wiley \& Sons Ltd.

Setiabudi, K.J., Siagian, H. and Tarigan, Z.J.H. (2021). The Effect of Transformational Leadership on Firm Performance Through ERP Systems and Supply Chain Integration in The Food and Beverage Industry. International Journal of Business Studies, 4(1), 6573, https://doi.org/10.9744/ijbs.4.1.65-73

Susanty, F. (2020, April 24). Small Businesses Resort to Online Channels to Survive Pandemic - Business - The Jakarta Post. 
Retrieved from www.thejakartapost.com/ news/2020/04/24/small-businesses-resort-toonline-channels-to-survive-pandemic.html

Tallon, P. P., Queiroz, M., Coltman, T., \& Sharma, R. (2019). Information Technology and The Search for Organizational Agility: A Systematic Review with Future Research Possibilities. Journal of Strategic Information Systems, 28(2), 218-237. doi.org/10.1016/ j.jsis.2018.12.002

Wingwon, B. (2012). Effects of Entrepreneurship, Organization Capability, Strategic Decision Making and Innovation toward the Competitive Advantage of SMEs Enterprises. Journal of Management and Sustainability, 2(1), $137-$
150. doi.org/10.5539/jms.v2n1p137

Wu, K. J., Tseng, M. L., Chiu, A. S. F., \& Lim, M. K. (2017). Achieving Competitive Advantage Through Supply Chain Agility Under Uncertainty: A Novel Multi-Criteria DecisionMaking Structure. International Journal of Production Economics, 190, 96-107. doi.org/ 10.1016/j.ijpe.2016.08.027

Yaghoobi, N. M., Bakhshimazdeh, M., \& Alikhasi, M. (2014). Analysing Key Concepts of Organisation: Knowledge Management, Competitive Intelligence and Competitive Advantage. International Journal of Services and Operations Management, 18(3), 321-341. doi.org/10.1504/IJSOM.2014.062234 